\title{
Anti-proliferative effect of Melissa officinalis on Human Colon Cancer Cell Line
}

Manuel Alejandro Encalada ${ }^{\mathrm{a}}$, Kelly Melissa Hoyos ${ }^{\mathrm{a}}$, Sheyla Rehecho ${ }^{\mathrm{a}}$, Izaskun Berasategi ${ }^{\mathrm{b}}$, Mikel García-Íñiguez de Ciriano $^{\mathrm{b}}$, Diana Ansorena ${ }^{\mathrm{b}}$, Iciar Astiasarán ${ }^{\mathrm{b}}$, Íñigo Navarro-Blasco ${ }^{\mathrm{c}}$, Rita Yolanda Cavero $^{\mathrm{d}}$, María Isabel Calvo ${ }^{\mathrm{a}^{*}}$

${ }^{a}$ Department of Pharmacy and Pharmaceutical Technology, Faculty of Pharmacy, University of Navarra, Irunlarrea s/n, 31008 Pamplona, Spain

${ }^{\mathrm{b}}$ Department of Nutrition, Food Science, Physiology and Toxicology, Faculty of Pharmacy, University of Navarra, Irunlarrea s/n, 31008 Pamplona, Spain

${ }^{c}$ Department of Chemistry and Soil Science, Faculty of Sciences, University of Navarra, Irunlarrea s/n, 31008 Pamplona, Spain

${ }^{\mathrm{d}}$ Department of Plant Biology (Botany), Faculty of Sciences, University of Navarra, Irunlarrea s/n, 31008 Pamplona, Spain

*Corresponding address: Department of Pharmacy and Pharmaceutical Technology, School of Pharmacy, University of Navarra, C/ Irunlarrea s/n, 31080 Pamplona, Spain. e-mail: mcalvo@unav.es 


\begin{abstract}
Melissa officinalis L. (Lamiaceae) is consumed as a traditional herbal tea in the Mediterranean region. The cytotoxic effect of the $50 \%$ ethanolic and aqueous extract, determined by the MTT and NR assays, was evaluated in vitro on Human Colon Cancer Cell Line (HCT-116), using Triton 10\% as positive control. The $50 \%$ ethanolic extract showed significant differences after 72 hours of treatment, reducing cell proliferation to values close to $40 \%$, even the lowest dose tested (5 $\mu \mathrm{g} / \mathrm{ml})$. In the MTT assay, the same extract caused the lowest cell viability with $13 \%$ at a concentration of $1000 \mu \mathrm{g} / \mathrm{ml}$ after $72 \mathrm{~h}$ of treatment, being a value lower than triton $10 \%$. The antioxidant activity was also confirmed evaluating the capacity of the extracts to scavenge ABTS and DPPH radicals, and IC50 values were highly correlated with the total phenolic and flavonoid content. Bioassay guided fractionation led to the isolation of an anti-proliferative compound, rosmarinic acid. Its structural elucidation was performed by HPLC/DAD/ESI/MS analysis. High dose of rosmarinic acid $(1000 \mu \mathrm{g} / \mathrm{ml})$ was clearly cytotoxic against HCT-116 cells, with a significant decrease in cell number since the earliest time point $(24 \mathrm{~h})$.
\end{abstract}

KeyWords: Lemon balm; Lamiaceae; Antioxidant; Cytotoxicity; HCT-116; RA.

\title{
Abbreviations:
}

AQE: Aqueous extract

HAE: $50 \%$ ethanolic extract

RA: Rosmarinic acid

TFC: Total flavonoid content

TPC: Total phenolic content

\section{Introduction}


Cancer is one of the major human diseases and causes considerable suffering and economic loss worldwide. Colorectal cancer (CRC) with 655,000 deaths worldwide per year, it is the fourth most common form of cancer in the United States and the third leading cause of cancer-related death in the Western world [1]. Therefore, further research is needed for the development of safe products for the prevention and treatment of all human cancers. Approximately $60 \%$ of drugs currently used for cancer treatment have been isolated from natural products [2] and the plant kingdom has been the most significant source. These include Vinca alkaloids, Taxus diterpenes, Camptotheca alkaloids, and Podophyllum lignans. Currently, there are 16 new plant-derived compounds being tested in clinical trials and of these 13 are being tested in phase I or II, and 3 are in phase III. Among these compounds, flavopiridol, isolated from the Indian tree Dysoxylum binectariferum, and mesoindigo, isolated from the Chinese plant Indigofera tinctoria, have been shown to exhibit anti-cancer effects with lesser toxicity than conventional drugs [3].

Epidemiological studies, experiments on laboratory animals and investigations of humans show that consumption of a diet rich in vegetables and fruits is associated with a low risk of some diseases including cardiovascular diseases and cancer. This beneficial effect has been attributed to the bioactive compounds of these natural products and first of all to phenolic compounds, due to their ability to act as efficient free radical scavengers. Many plants possess antioxidant activities and their consumption was recommended $[4,5]$. Therefore, the phytochemicals present in herbal products, marketed as dietary supplements, may act as preventative or therapeutic agents similar to over-the counter (OTC) and prescription drugs.

Lemon balm, M. officinalis L. is one of the most used medicinal plants in Europe and the Mediterranean region, as a herbal tea for their aromatic, digestive and antispasmodic properties in nervous disturbance of sleep and functional gastrointestinal disorders [6]. The leaves emit a distinct fragrant lemon odour when bruised. The chemical composition is essential oil, polyphenolic compounds: caffeic acid derivatives in large proportions, such as RA, trimeric compounds, and also some flavonoids such as luteolin-7-0-glucoside. Some pharmacological properties have been attributed 
to the principal constituents. Essential oil is considered to be the therapeutic principle mainly responsible for most of the activities mentioned, spasmolytic, antimicrobial, antitumor and antioxidant, mainly [7]; but plant phenolics, especially RA, are involved too. Enriched extracts containing RA are used as a virostatic against herpes viruses, alcohol extracts as sedatives and the essential oil as a digestive aid in pharmaceutical preparations [8]. Moreover, its neuroprotective properties have been demonstrated using an in vitro cellular model with the PC12 (rat pheochromocytoma) cell line, as well as its neurological activities with methanolic extracts being more effective than aqueous extracts [9].

In the course of our interest in biological and industrial applications from this plant [9-12], this paper focuses on the analysis of the anti-proliferative activity of $M$. officinalis extracts, fractions and RA. In-vitro cytotoxicity analysis, using MTT and NR assays, indicated that this plant was very effective against human colon cancer cell line (HCT-116). These results pointed to the potential use of M. officinalis as an anti-cancer agent.

\section{Material and Methods}

\section{Chemicals}

Cell culture products as well a media were obtained from Gibco (Barcelona, Spain). Chemical reagents were purchased from Sigma-Aldrich (Spain). RA (purity $\geq 99 \%$ ) was obtained form Extrasynthèse (Genay, France).

\section{Preparation of Extracts}

M. officinalis dried leaves were purchased from Plantarom S.L. (Barcelona, Spain). 50\% ethanolic (HAE) and aqueous (AQE) extracts of plant were prepared [11]. Both extracts presented a very similar percentage of extraction (HAE: 23.01\%; AQE: 21.76\% dry weight base).

Determination of the scavenging activity, total phenolic (TPC) and flavonoid (TFC) content 
Two different methods were used for the evaluation of the antioxidant activity: DPPH radical scavenging assay [13], and 2,2-azinobis-(3-ethylbenzthiazoline-6-sulphonic acid (ABTS) assay [14]. The results were compared with BHT and BHA, two of the most usually used synthetic antioxidants. The antioxidant activity was expressed as IC50 values, which were calculated by non-linear regression with a one phase exponential association equation using GraphPad Prism version 4.0.

TPC and TFC of samples were quantified spectrophotometrically according to the published procedures $[15,16]$. All determinations were carried out in triplicate and the mean values were used.

Determination of the cytotoxicity in HCT-116 cells (Human Colorectal Carcinoma Cells)

\section{Cell Culture}

HCT-116 cells were obtained from the American Type Culture Collection. Cells were grown in Dulbecco's modified eagle's medium (DMEM) supplemented with $10 \%$ heat-inactivated fetal bovine serum (FBS), penicillin $(10 \mathrm{U} / \mathrm{ml})$, streptomycin $(10 \mu \mathrm{g} / \mathrm{ml})$ and $0.2 \mathrm{mM}$ sodium pyruvate. Cultures were incubated in the presence of $5 \% \mathrm{CO}_{2}$ at $37^{\circ} \mathrm{C}$ and $100 \%$ relative humidified atmosphere.

\section{Determination of Cell Survival by the MTT Reduction Assay}

HCT-116 cells were seeded in 96-well microplates at a density of $10 \times 10^{3}$ cells/well and grown for 24 $\mathrm{h}$ at $37{ }^{\circ} \mathrm{C}$ in $5 \% \mathrm{CO}_{2}$ prior to the addition of test samples. Cells were treated with various concentrations of samples $(5-1000 \mu \mathrm{g} / \mathrm{ml})$ dissolved in Dulbecco's phosphate buffered saline (PBS). After 24, 48 and $72 \mathrm{~h}$ of incubation, cell viability was determined using the colorimetric MTT assay. MTT solution at $5 \mathrm{mg} / \mathrm{ml}$ was dissolved in $1 \mathrm{ml}$ of PBS, and $200 \mu \mathrm{L}$ of it was added to each of the 96 wells. The wells were wrapped with aluminium foil and incubated at $37{ }^{\circ} \mathrm{C}$ for 90 minutes. The solution in each well containing media, unbound MTT and dead cells were removed by suction and $100 \mu \mathrm{L}$ of DMSO was added to each well. Then the plates were shaken and cell survival (\%) was measured as reduction of MTT into formazan at $550 \mathrm{~nm} .10 \mu \mathrm{L}$ of $10 \%$ Tritón ${ }^{\circledR}$ X-100 solution was used as positive control, because in biological research, this detergent is used for lysing cells. Untreated cells (at $0 \mu \mathrm{g} / \mathrm{ml}$, vehicle alone) were chosen as the negative control Controls and samples 
were assayed in triplicate for each concentration and replicated three times. The absorbance values were converted into percentages of cell viability using the following formula: Cell viability $(\%)=($ Abs sample / Abs control) x 100

Neutral Red (NR) Assay

$5 \times 10^{3}$ cells were plated in 96-well microplates and incubated at $37{ }^{\circ} \mathrm{C}$ in $5 \% \mathrm{CO}_{2}$. After $24 \mathrm{~h}$, cells were treated with various concentrations of samples $(5-1000 \mu \mathrm{g} / \mathrm{ml})$ dissolved in PBS. After 24,48 and $72 \mathrm{~h}$ of incubation, cell viability was determined using the colorimetric NR assay. Neutral red solution at a final concentration of $50 \mu \mathrm{g} / \mathrm{ml}$ in culture medium and $200 \mu \mathrm{L}$ of it was added to each of the 96 wells. The wells were wrapped with aluminium foil and incubated at $37{ }^{\circ} \mathrm{C}$ for 90 minutes. The solution in each well containing media, unbound NR and dead cells were removed by suction and with $100 \mu \mathrm{L}$ of a mixture with $1 \%$ formaldehyde- $1 \% \mathrm{CaCl}_{2}$ and the dye extracted with $0.2 \mathrm{ml}$ of $1 \%$ acetic acid in 50\% ethanol was added to each well. Then the plates were shaken and cell survival (\%) was measured at $540 \mathrm{~nm}$. The absorbance values were converted into percentages of cell viability using the same formula as for the MTT assay.

Bioassay-guided fractionation and isolation of cytotoxic and antioxidant compound A multi-step fractionation procedure was carried out in order to separate the different constituents of the HAE, using Sephadex LH-20 as stationary phase About $3.5 \mathrm{~g}$ of HAE, was dissolved in $2 \mathrm{ml}$ of $50 \%$ ethanol and chromatographic separation was achieved with $50 \%$ ethanol as mobile phase, yielding six fractions (F1: $0.45 \mathrm{~g} ; \mathrm{F} 2: 1.74 \mathrm{~g}$; F3: $0.61 \mathrm{~g}$; F4: $0.27 \mathrm{~g}$; F5: $0.47 \mathrm{~g}$; F6: $0.31 \mathrm{~g}$ ). F5 showed antioxidant and antiproliferative activity and $0.31 \mathrm{mg}$ of the active compound from this fraction (1) was isolated by preparative reversed-phase HPLC, using water (85\%) and acetonitrile $(15 \%)$ as eluents. The purity of peak 1 ( $>95 \%)$ was checked by a Diode Array Detector coupled to the HPLC system, and the identification was performed by HPLC-DAD, HPLC-MS comparing the isolated compound with authentic reference sample or data reported in the literature. 


\section{HPLC-DAD and HPLC-MS Analysis}

The extracts and fractions were analyzed by HPLC using a Waters (Milford, MA, USA) 600E multisolvent delivery system, a Waters U6K sampler and a Waters 991 photodiode-array detector. Chromatography was performed on a C18 reversed-phase column (Nova-Pak, $150 \mathrm{~mm}$ x 3.9 mm., 4 $\mu \mathrm{m}$, Waters) at $25^{\circ} \mathrm{C}$. Detection was a range between $210-500 \mathrm{~nm}$. The mobile phase was formed by acetonitrile (A) and twice distilled water adjusted to $\mathrm{pH} 3$ with acetic acid (B) in different proportions. The elution system was: $0-1 \mathrm{~min}, 93-90 \%$ of $\mathrm{B} ; 1-5 \mathrm{~min}, 90 \%$ of $\mathrm{B} ; 5-8 \mathrm{~min}, 90-85 \%$ of $\mathrm{B} ; 8-13 \mathrm{~min}$, $85 \%$ of $\mathrm{B} ; 13-30 \mathrm{~min}, 85-40 \%$ of $\mathrm{B}$ and $30-40 \mathrm{~min}, 40 \%$ of $\mathrm{B}$. The flow rate employed was $1 \mathrm{ml} / \mathrm{min}$. HPLC-MS analysis was performed using a HP 1100L liquid chromatograph linked to a HP 100 MSD mass spectrometer with an API/electrospray interface (Agilent Technologies, Palo Alto, CA, USA). The column, time period and flow rate were similar to those used during the HPLC-DAD analysis. The mass spectrometer operating conditions were: gas temperature, $350{ }^{\circ} \mathrm{C}$; nitrogen flow rate, $10 \mathrm{~L} / \mathrm{min}$; nebulizer pressure $30 \mathrm{psi}$; quadrupole; temperature, $25^{\circ} \mathrm{C}$; capillary voltage, $3500 \mathrm{~V}$. The mass spectrometer was operated in positive and negative mode at $12 \mathrm{eV}$.

\section{Statistical Analysis}

Data are mean \pm SD of three independent experiments. Cell assays were analyzed by ANOVA followed by Dunnett's test whereas IC50 values were analyzed by Student test.

\section{Results and Discussion}

Botanicals and plant foods are also a source of antioxidants, which play a special role in chemoprevention. In fact, plant extracts and isolated compounds are formulated in a great variety of dietary supplements regarding antioxidant and protective effects against ROS, of which an excess is associated with ageing, cataracts, cardiovascular and neurodegenerative diseases and certain types of cancer. The antioxidant activity was evaluated in different in vitro models (Table 1). The antioxidant capacity is described quantitatively by the concentration of antioxidant needed to scavenge $50 \%$ of 
either $\mathrm{DPPH}^{\bullet}$ or $\mathrm{ABTS}^{\bullet+}$ which is referred to as the IC50. The IC50 was obtained from the graph of the percentage of scavenged radical versus the concentration of antioxidant. Both $\mathrm{DPPH}^{\bullet}$ and $\mathrm{ABTS}^{\bullet+}$ radicals have been widely used to investigate the ability of plant extracts and fractions and/or pure compounds of those, to act as free radical-scavengers or hydrogen donors. Both extracts tested in this work were capable of scavenging $\mathrm{DPPH}^{\bullet}$ radicals. Activity of $\mathrm{HAE}(\mathrm{IC} 50=11.04 \pm 0.72 \mu \mathrm{g} / \mathrm{ml})$ and AQE (IC50=17.11 $\pm 1.70 \mu \mathrm{g} / \mathrm{ml})$ demonstrated a higher scavenging capacity compared to other medicinal plants previously analyzed $[10,13]$. The $\mathrm{ABTS}^{\bullet+}$ assay, revealed similar results as the $\mathrm{DPPH}^{\bullet}$ assay $(8.60 \pm 1.48$ and $9.22 \pm 1.28 \mu \mathrm{g} / \mathrm{ml}$, respectively). Extremely high and negative correlation $(* \mathrm{P}<0.01)$ was observed between TPC and IC50 for DPPH ${ }^{\bullet}$ radical scavenging activity $\left(r^{2}=-0.955\right)$, and $\mathrm{ABTS}^{\bullet+}$ radical scavenging activity $\left(r^{2}=-0.967\right)$. Results also showed that TFC had high and statistically significant negative correlation $(* * \mathrm{P}<0.05)$ with $\mathrm{DPPH}^{\bullet}$ radical scavenging activity $\left(r^{2}=\right.$ $0,885)$ and $\mathrm{ABTS}^{\bullet+}$ radical scavenging activity $\left(r^{2}=-0.863\right)$. Therefore, good correlation suggests that phenolic compounds, no only flavonoid type, play an important role as antioxidants. In the same way, various studies correlating lemon balm's medicinal properties with its antioxidant activity and phenolic profile have been published. Despite, the usage of various methods for the evaluation of antioxidant capacity makes comparison even more difficult, the same results have been found by other authors; it was previously reported that aqueous methanolic extract of $M$. officinalis caused a concentrationdependent inhibition of lipid peroxidation, and phenolic components present demonstrated antioxidant activity [17]. Hydroalcoholic extracts have also shown significant antioxidative activities, by free radical scavenger effect on DPPH, partly in relation to their RA content [18].

The initial screenings for plants used for cancer treatment are cell-based assays using established cell lines, in which the toxic effects of plant extracts or isolated compounds can be measured. Cytotoxic screening models supply important preliminary data to select plant extracts or compounds with potential antineoplastic properties. In addition, cytotoxic assays do not provide false negative results since they consider plant extracts or compounds which affect cell viability. In this paper, the HAE and AQE were tested on HCT-116 tumour cell lines by the tetrazolium MTT and the 
neutral red (NR) assays. The NR assay is based on the uptake of neutral red, a supravital dye, and its accumulation in the liposome of viable uninjured cells, and it is based on the reduction of the soluble yellow MTT tetrazolium salt (purple compound) to a blue insoluble MTT formazan product by mitochondrial succinic dehydrogenase [19]. Various studies demonstrate that both the NR and MTT in vitro cytotoxicity assays can be applied to screening the acute toxicities of compounds and to identifying interactions when combinations of them are used [20]. The good agreement $(r=0.939)$ between the ranking of the values of both methods suggests that although each test has a different physiological endpoint, the assays yield comparable data. Conversely, the differential sensitivities between the NR and MTT assays for some antineoplastic drugs might prompt the inclusion of both assays in a battery of test methods. The cell proliferation inhibition was registered at six different doses and three times (Fig. 1). The profile of results obtained by the MTT and NR assays for both extracts was similar. In the case of $A Q E$, significant $(\mathrm{P}<0.05)$ or very significant $(\mathrm{P}<0.01)$ differences were found in comparison to negative control at higher doses tested $(1000 \mu \mathrm{g} / \mathrm{ml})$, reaching values similar to triton (positive control), after 24, 48 and $72 \mathrm{~h}$ of treatments (Fig. 1a-b). Figure 1d shows that HAE showed significant differences after 72 hours of treatment, reducing cell proliferation to values close to $40 \%$, even the lowest dose $(5 \mu \mathrm{g} / \mathrm{ml})$. In the MTT and NR assays; the HAE extract caused the lowest cell viability with $13 \%$ at a concentration of $1000 \mu \mathrm{g} / \mathrm{ml}$ after $72 \mathrm{~h}$ of treatment, being a value lower than triton $10 \%$ (Fig. 1c-d). Recently, many plant extracts and natural products, especially phenolics, with high antioxidant activity have shown antiproliferative effects in different cell lines including NCIH82 (human, small cell lung, carcinoma), DU-145 (human, prostate, carcinoma), Hep-3B (human, black, liver, carcinoma, hepatocellular), K-562 (human chronic myeloid leukemia), MCF-7 (human, breast, adenocarcinoma), PC-3 (human, prostate, adenocarcinoma) and MDA-MB-231 (human, breast, adenocarcinoma) [21, 22]. Fractionation of the HAE by Sephadex LH-20 CC yielded six fractions. The antioxidant activity evaluation tests of the fractions showed that, the most active fractions were F5 against DPPH radical and $\mathrm{ABTS}^{\bullet+}$ assay $(1.84 \pm 0.06$ and $4.44 \pm 0.25 \mu \mathrm{g} / \mathrm{ml}$, respectively) (Table 1). The same correlations were also obtained between TPC and TFC with antioxidant activity. In cell viability 
assays, fraction F5 was also the most active against the HCT-116 cell line at $1000 \mu \mathrm{g} / \mathrm{ml}, 24,48$ and 72 hours after treatment (Fig. 2). As can be seen the percentages obtained are similar to triton.

The HPLC-DAD analysis of fraction F5 revealed the presence of a main compound (1) (95\% of the composition) and several small peaks in less proportion (5\%). The active compound (1) of this fraction was isolated by preparative reversed-phase HPLC and the structure was elucidated as an ester of caffeic acid and 3-(3,4-dihydroxyphenyl)lactic acid, rosmarinic acid [23]. Compound 1 was obtained as a finely crystalline light yellow, mp $165-174^{\circ} \mathrm{C}(\mathrm{dec}),.[\alpha]_{\mathrm{D}}{ }^{20}-32.5^{\circ} .(\mathrm{c} 0.05, \mathrm{MeOH}), \mathrm{m} / \mathrm{z}=$ $360.08[\mathrm{M}]^{+}$. The UV absorbance maximum at $327 \mathrm{~nm}$ and a shoulder at $290 \mathrm{~nm}$ indicate the nature of phenolic acid with two aromatic rings. These observations were confirmed by the LC-MS analyses of compound 1, where the most important ion fragmentations were $\mathrm{m} / \mathrm{z}=359.07[\mathrm{M}-\mathrm{H}]^{-}, 197.04[\mathrm{M}-\mathrm{H}-$ $162]^{-}, 179.03$ [M-H-180]', $161.02[\mathrm{M}-\mathrm{H}-198]^{-}$, corresponding to the deprotonated form of 3-(3,4dihydroxyphenyl)lactic and caffeic acids and their dehydrated forms. RA is a polyphenolic compound present in high amount in many herbal plants of the Lamiaceae family such as rosemary, lemon balm, sage, oregano or savory. There is consensus that the significant antioxidant properties by lemon balm are mainly due to the large quantities of RA [24]. Several biological activities have been described for RA in relation to its antioxidant activity, the most known being anti-inflammatory, antiviral, antimicrobial, neuroprotective and neurological properties, and anticancer against various cell lines [9, 25-28]. However, this study is the first to establish a relationship between the antioxidant activity of RA and this celll line. HCT-116 cells were treated with RA $(5-1000 \mu \mathrm{g} / \mathrm{ml})$ for 24,48 and $72 \mathrm{~h}$, and as shown in Table 2, high dose was clearly cytotoxic, with a significant decrease in cell number since the earliest time point $(24 \mathrm{~h})$.

In conclusion, the results of this study have shown a high correlation between the phenolic content, antioxidant effect and antiproliferative activity in extracts and fractions. For this reason, RA could contribute, at least in part, induced cytotoxic effect in this cell line. Future research would be needed to determine the chemical nature of other compounds present in lemon balm, and possible synergism of action with RA. Considering our results along with the preliminary studies, we suggest 
that RA in combination with the anticancer drugs may offer a good strategy for the treatment of a human colon cancer.

\section{Acknowledgements}

We thank the "Proyecto AGL2008-01099/ALI" and "CONSOLIDER 2010-CARNISENUSA CSD2007-00016" (Ministerio de Ciencia e Innovación), and the "Plan Investigador de la Universidad de Navarra" (PIUNA) for their contribution to the financial support of this work.

\section{References}

1. Cancer. National Cancer Institute. 2009. www.cancer.gov/cancertopics/commoncancers

2. Gordaliza M (2009) Natural products as leads to anticancer drugs. Clin Transl Oncol 9:767-776

3. Saklani A, Kutty SK (2008) Plant-derived compounds in clinical trials. Drug Discov Today 13:161171

4. Wattenberg LW (1998) Chemoprevention of carcinogenesis by minor dietary constituents: Symposium introduction. Pharm Biol 36:6-7

5. Yang CS, Chung JY, Yang G, Chhabra SK, Lee MJ (2000) Tea and tea polyphenols in cancer prevention. J Nutr 130:472S-478S

6. Bisset NG (1994) Herbal Drugs and Phytopharmaceuticals: A handbook for practice scientific basis ( $1^{\text {st }}$ ed.). Stuttgart, Germany: Medpharm GmbH Scientifiv Publisher

7. de Sousa A C, Alviano DS, Blank AF, Alves PB, Alviano CS, Gattass CR (2004) Melissa officinalis

L. essential oil: antitumoral and antioxidant activities. J Pharm Parmacol 56:677-681

8. Kucera LS, Cohen RA, Herrmann EC (1965) Antiviral Activities of Extracts of the Lemon Balm Plant. Ann NY Acad Sci 130:474-482

9. López V, Martín S, Gómez-Serranillos MP, Carretero ME, Jäger AK, Calvo MI (2009) Neuroprotective and Neurological Properties of Melissa officinalis. Neurochem Res 34:1955-1961 
10. López V, Akerreta S, Casanova E, Garcia-Mina JM, Cavero RY, Calvo MI (2007) In vitro antioxidant and anti-rhizopus activities of Lamiaceae herbal extracts. Plant Food Hum Nutr 62:151155

11. García-Iñiguez de Cirano M, Larequi E, Rehecho S, Calvo MI, Cavero RY, Navarro-Blasco I, Astiasarán I, Ansorena D (2010a) Selenium, iodine, w-3 PUFA and natural antioxidant from Melissa officinalis L.: a combination of components from healthier dry fermented sausages formulation. Meat Sci 85:274-279

12. García-Iñiguez de Ciriano M, Rehecho S, Calvo MI, Cavero RY, Navarro I, Astiasarán I, Ansorena D (2010b) Effect of lyophilized water extracts of Melissa officinalis on the stability of algae and linseed oil-in-water emulsion to be used as a functional ingredient in meat products. Meat Sci 85:373377

13. López V, Akerreta S, Casanova E, García-Mina JM, Cavero RY, Calvo MI (2008) Screening of Spanish medicinal plants for antioxidant activities. Pharm Biol 46:602-609

14. López V, Jäger AK, Akerreta S, Cavero RY, Calvo MI (2010) Antioxidant activity and phenylpropanoids of Phlomis lychnitis L.; A traditional herbal tea. Plant Food Hum Nutr 65:179-185

15. Pueyo IU, Calvo MI (2009) Assay conditions and validation of a new UV spectrophotometric method using microplates for the determination of polyphenol content. Fitoterapia 80:465-467

16. Rehecho S, Hidalgo O, García-Iñiguez de Cirano M, Navarro I, Astiasarán I, Ansorena D, Cavero RY, Calvo MI (2011) Chemical composition, mineral content and antioxidant activity of Verbena officinalis L. LWT-Food Sci Technol 44:875-882

17. Hohmann J, Zupko I, Redei D, Csanyi M, Falkay G, Mathe I, Janicsak G (1999) Protective effects of the aerial parts of Salvia officinalis, Melissa officinalis and Lavandula angustifolia and their constituents against enzyme-dependent and enzyme-independent lipid peroxidation. Planta Med $65: 576-578$

18. Ivanova D, Genova D, Chervenkov T, Yankova T (2005) Polyphenols and antioxidant capacity of Bulgarian medicinal plants. J Ethnopharmacol 96:145-150 
19. Mosmann T (1983) Rapid colorimetric assay for cellular growth and survival: application to proliferation and cytotoxicity assays. J Immunol Methods 65:55-63

20. Borenfreunds E, Babich H, Martin-Alguacil N (1998) Comparisons of two in vitro cytotoxicity assays the neutral red (NR) and tetrazolium MTT tests. Toxicol in Vitro 2:1-6

21. Ma PL, Zhao PR, Tian AQ, Zhang S (2006) The Effect of Prunella Vulgaris L on Eca109 Cells. J Basic Clin Oncol 19:199-200

22. Yesil-Celiktas O, Sevimli C, Bedir E, Vardar-Sukan F (2010) Inhibitory effects of Rosemary extracts, carnosic acid and rosmarinic acid on the growth of various human cancer cell lines. Plant Food Hum Nutr 65:158-163

23. Wang H, Provan GJ, Helliwel K (2004) Determination of rosmarinic acid and caffeic acid in aromatic herbs by HPLC. Food Chem 87:307-311

24. Petersen M, Simmonds MS (2003) Molecules of Interest Rosmarinic acid. Phytochemistry 62:121125

25. Osakabe N, Takano H, Sanbongi C, Yasuda A, Yanagisawa R, Inoue K, Yoshikawa T (2004) Antiinflammatory and anti-allergic effect of rosmarinic acid (RA); inhibition of seasonal allergic rhinoconjunctivitis (SAR) and its mechanism. Biofactors 21:127-131

26. Swarup V, Ghosh J, Ghosh S, Saxena A, Basu A (2007) Antiviral and anti-inflammatory effects of rosmarinic acid in an experimental murine model of Japanese encephalitis. Antimicrob Agents Chemother 51:3367-3370

27. Xavier C, Lima C, Fernandes-Ferreira M, Pereira-Wilson C (2009) Salvia fruticosa, Salvia officinalis, and rosmarinic acid induced apoptosis and inhibit proliferation of human colorectal cell lines: the role in mapk/erk pathway. Nutr Cancer 61:564-571

28. Xu YC, Xu GL, Liu L, Xu DS, Liu JW (2010) Anti-invasion effect of rosmarinic acid via the extracellular signal-regulated kinase and oxidation-reduction pathway in Ls174-T cells. J Cell Biochem 111:370-379 
Table 1. Total phenol and flavonoids, antioxidant activity of Melissa officinalis extracts and fractions.

\begin{tabular}{ccccc}
\cline { 2 - 5 } & \% TPC & $\% \mathrm{TFC}$ & $\mathrm{DPPH}$ & ABTS \\
& $(\mathrm{mg} / 100 \mathrm{~g})$ & $(\mathrm{mg} / 100 \mathrm{~g})$ & $\mathrm{IC}_{50}(\mu \mathrm{g} / \mathrm{ml})$ & $\mathrm{IC}_{50}(\mu \mathrm{g} / \mathrm{ml})$ \\
\hline AQE & $1980.54 \pm 162.22$ & $672 \pm 0.04$ & $17.11 \pm 1.70$ & $9.22 \pm 1.28$ \\
HAE & $3407.32 \pm 360.47$ & $927 \pm 0,08$ & $11.04 \pm 0.72$ & $8.60 \pm 1.48$ \\
\hline F1 & $33.72 \pm 2.71$ & $<0.5$ & $218.43 \pm 0.85$ & $>500$ \\
F2 & $399.70 \pm 10.52$ & $33.48 \pm 1.87$ & $37.96 \pm 1.27$ & $63.98 \pm 5.14$ \\
F3 & $846.42 \pm 9.55$ & $78.70 \pm 2.34$ & $3.39 \pm 0.07$ & $8.30 \pm 0.73$ \\
F4 & $196.90 \pm 5.01$ & $87.65 \pm 3.46$ & $7.13 \pm 0.09$ & $13.38 \pm 0.81$ \\
F5 & $1423.93 \pm 142.33$ & $269.48 \pm 9.29$ & $1.84 \pm 0.06$ & $4.44 \pm 0.25$ \\
F6 & $178.32 \pm 2.65$ & $97.58 \pm 3.12$ & $8.62 \pm 0.14$ & $21.79 \pm 2.47$ \\
\hline BHA & - & - & $3.88 \pm 0.72$ & $2.79 \pm 0.13$ \\
BHT & - & - & $5.05 \pm 0.63$ & $5.22 \pm 0.75$ \\
\hline
\end{tabular}


Table 2. Percent cell survival of rosmarinic acid (1) against HCT-116 colon human tumour cell lines.

\begin{tabular}{|c|c|c|c|c|}
\hline \multirow[b]{2}{*}{ Doses $(\mu \mathrm{g} / \mathrm{ml})$} & \multirow[b]{2}{*}{ Method } & \multicolumn{3}{|c|}{ Time (hour) } \\
\hline & & $24 \mathrm{~h}$ & $48 \mathrm{~h}$ & $72 \mathrm{~h}$ \\
\hline \multirow[t]{2}{*}{5} & MTT & $76.47 \pm 5.41$ & $75.24 \pm 6.53$ & $65.32 \pm 7.51$ \\
\hline & NR & $75.50 \pm 9.74$ & $6.217 \pm 5.59$ & $65.19 \pm 9.16$ \\
\hline \multirow[t]{2}{*}{500} & MTT & $70.59 \pm 2.97$ & $60.70 \pm 5.77$ & $58.87 \pm 9.30$ \\
\hline & NR & $74.17 \pm 5.12$ & $45.01 \pm 3.26$ & $62.11 \pm 7.15$ \\
\hline \multirow[t]{2}{*}{1000} & MTT & $19.36 \pm 5.07$ & $18.82 \pm 3.56$ & $18.30 \pm 2.98$ \\
\hline & NR & $14.84 \pm 4.15$ & $10.46 \pm 1.87$ & $10.17 \pm 2.03$ \\
\hline \multirow[t]{2}{*}{$C(+)$} & MTT & $20.14 \pm 7.09$ & $19.39 \pm 3.45$ & $19.55 \pm 4.32$ \\
\hline & NR & $10.40 \pm 2.11$ & $10 \pm 2.57$ & $10 \pm 1.99$ \\
\hline$C(-)$ & & & $100 \pm 0.00$ & \\
\hline
\end{tabular}



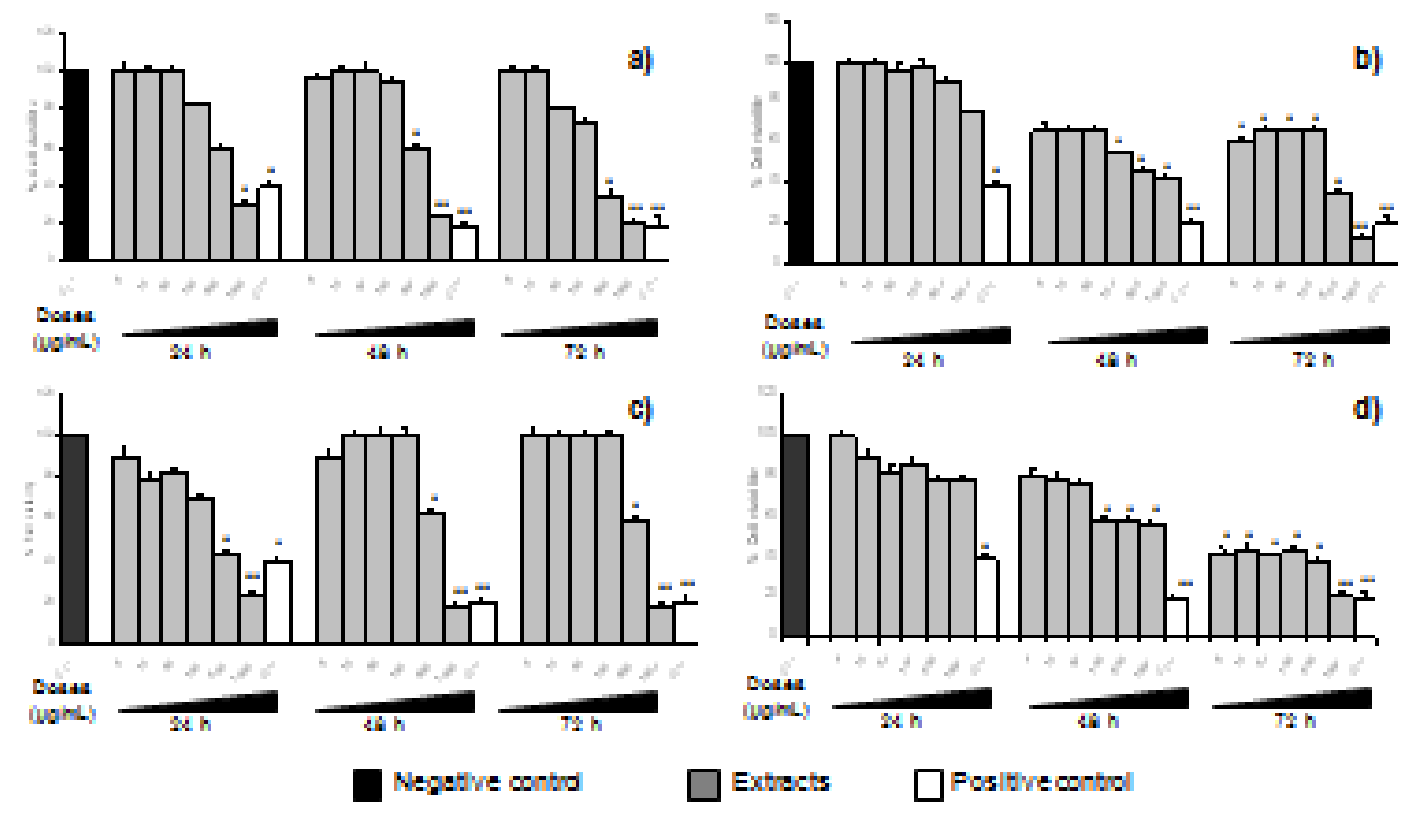

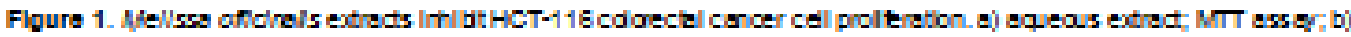

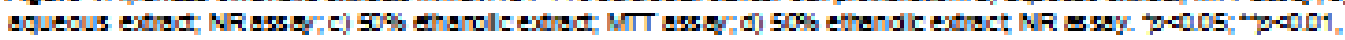
compared to the cortiol. 

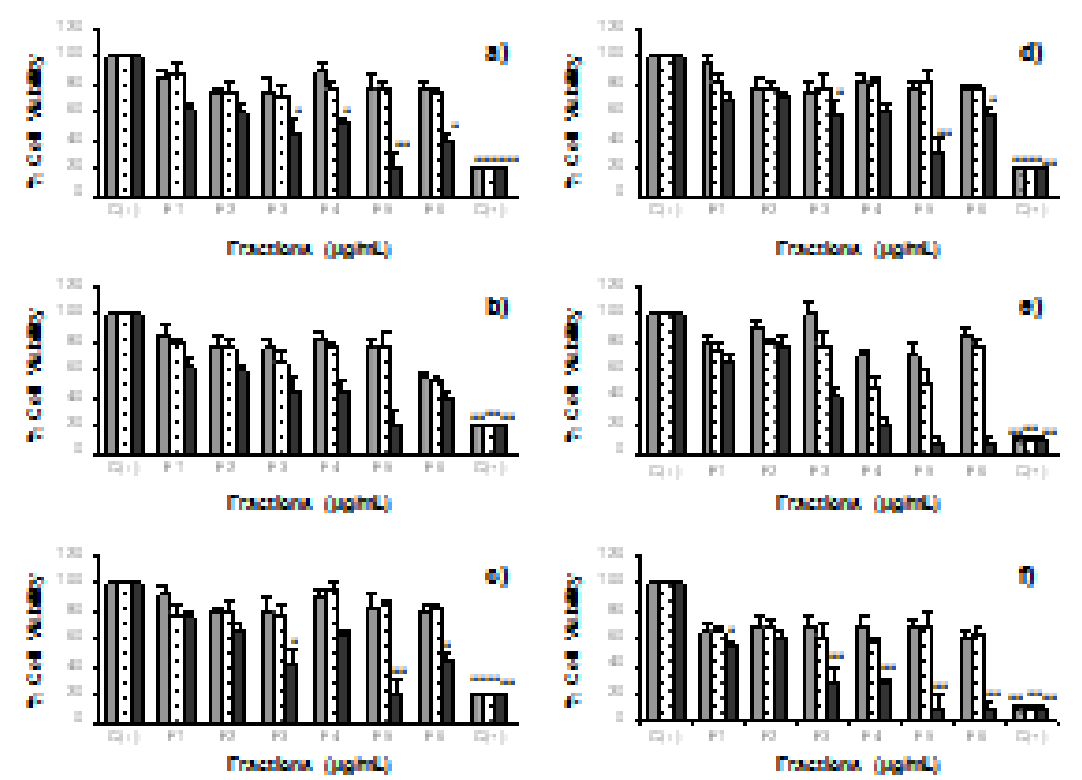

$$
\square^{5 \mathrm{mg} / \mathrm{ml}} \text { 因 } 500 \mathrm{mg} / \mathrm{ml} \square^{1000 \mathrm{mg} / \mathrm{ml}}
$$

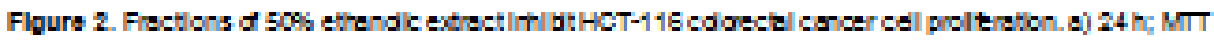

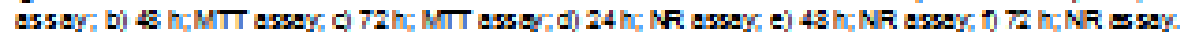

